\title{
Developing ELP Students' Reading Skills through a Blended Learning Approach
}

\author{
Chams Eddine Lamria*(i), Hafida Hamzaoui ${ }^{a} 1$ (iD \\ a TlemcenUniversity, English Department, Tlemcen, 13000, Algeria
}

Received 1 December 2017 | Received in revised form 13 March 2018 | Accepted 27 March 2018

\begin{abstract}
APA Citation:
Lamri, C. E. \& Hamzaoui, H. (2018). Developing ELP Students' reading skills through a blended learning approach. Eurasian Journal of Applied Linguistics, 4(2), 389-407. doi: 10.32601/ejal.464204
\end{abstract}

\begin{abstract}
Algerian law students are required to read and comprehend legal texts written in English in order to obtain managerial and regulatory rules knowledge. However, despite the efforts done by English for Law Purposes teachers, students still have language difficulties in general and are not able to comprehend texts related to their specialty in specific. Two main reasons are at the source of this problem: the limited instruction time and students' lack of motivation. Hence, this paper reports on an experimental study undertaken with nineteen $1^{\text {st }}$ year law Master's students who have learned English for at least 10 years and whose proficiency level is estimated to be intermediate. The experiment consisted in teaching them English using the blended approach via a Moodle platform. This ELP blended course based on Content and Language Integrated Learning approach, aimed to develop their reading comprehension. The results showed that this teaching approach was interesting at two levels. First, it allowed students' exposure to a wide variety of law texts and related activities in spite of the low time load allocated to English teaching. Second, it raised students' motivation as they could have access to many activities in their free time, select the ones to deal with, have feedback and discuss their difficulties with their mates or their instructor. Moreover, findings revealed that students involved in the experiment obtained higher scores in reading tests than the students who were not. The main conclusion drawn is that the blended approach combined with CLIL helped ELP students to develop their content knowledge and improve their reading competence in a short span of time.
\end{abstract}

(C) 2018 EJAL \& the Authors. Published by Eurasian Journal of Applied Linguistics (EJAL). This is an open-access article distributed under the terms and conditions of the Creative Commons Attribution license (CC BY-NC-ND) (http://creativecommons.org/licenses/by-nc-nd/4.0/).

Keywords: ELP teaching; reading skill; blended approach; CLIL; Moodle platform

\section{Introduction}

Though the French language has deep roots in the Algerian history, nowadays English teaching is expanding rapidly as a large proportion of the population is asking for learning this language (students, engineers, businessmen etc.). Indeed,

\footnotetext{
* Corresponding author.

E-mail address: lamrichamseddine@yahoo.fr

1 hamzaouihafida@yahoo.fr
} 
with the globalization process and the world exchange, English has imposed itself as a means of communication.

Consequently, ESP is taught in Algerian universities to achieve specific learners' needs, and meet the socioeconomic requirements. Therefore, different English language skills are focused in the various disciplines in order to help students achieve a better performance in the academic field as well as in the workplace. A case in point is that of ELP students who need to learn how to decode and comprehend specific types of English texts through reading tasks. However, achieving comprehension when reading authentic complex texts needs considerable teaching time; then to compensate for shortness of time, technology is widely used nowadays by ESP practitioners. With the availability of internet, teachers have adopted the blendedlearning approach to intensify students' exposure to the language (Marsh, 2012). However, while this teaching approach is widely used in some developed countries, it is still in its infancy in Algeria.

Before engaging in the study, it is important to set the background in which it was undertaken. Therefore, this paper will first describe the linguistic situation in Algeria from a historical perspective, and then present the English language needs of Algerian lawyers and administrators, to display later the challenges of reading in English for these professionals and the use of technology for teaching purposes. Thereafter, a report of the procedure and results of the present study will be displayed. The latter is based on the hypothesis that adopting a course based on Content and Language Integrated Learning (CLIL) and using a blended approach to teach ELP will better motivate learners and help them to improve their reading competence in a short span of time.

\subsection{Languages in Algeria}

Historically, Algeria lived under the French colonial rule from 1830 to 1962. During this period, the Koranic schools, known as Zawiyat and Madaris, played a major role to protect and preserve Islam and the Arabic language against the huge wave of colonialism which affected the Algerian society culturally and linguistically. After independence, the Algerian government launched a series of reforms to regain the lost Algerian identity. Language and education constituted the major tools to promote this ideology. As specified in the Algerian constitution of 1963, Modern Standard Arabic was recognized as the only official language of the country. Initially French was used in all aspects of life; then, Algerians were obliged to readapt themselves to this new linguistic situation. In this vein, Gordon (1966) writes: "Algeria's future will remain a fascinating case study for Orientalists and for those interested in 'development' and 'modernisation'." (p. 246). Indeed, Algerian policy makers and language planners had to cope with a complex linguistic situation because of the coexistence of different varieties of Arabic, French and Berber. This situation creates a kind of discord between "French, the colonial language, and Arabic, the new national language; 
Classical Arabic versus colloquial Algerian Arabic; and the various Berber dialects versus Arabic" (Tabory \& Tabory, 1987).

When Chadli Bendjedid was elected as third president of the independent Algeria (1979-1992), pupils started learning French from the fourth year of primary school and English from the middle school as a second foreign language.

After the fall of Berlin Wall in 1989, an ideological shift from the 'socialist' regimes of the Soviet Union and Eastern Europe to the international social and economic trends was adopted by almost all countries. Algeria was not an exception with its guided insertion into the globalization phenomenon. Algeria started to readapt its socioeconomic policy and significant changes were made in the organisation of workplace systems. Therefore, some specific groups of Algerians were in need of English to interact in their context. In this context, Miliani (2003) states that "the introduction of English is being heralded as the magic solution to all possible ills including economic, technological and educational ones" (p.13). In the beginning of the 1990s, the Algerian government introduced English as a subject at the primary school level instead of French. It was believed that implementing a neutral language in education, namely English, will disconnect Algerians from colonists' culture. In this vein, Coleman (2010) explains:

It was felt that English as a historically neutral language in the Algerian context would be able to play the modernising role that was hoped for from French but without the colonialist and non-Islamic associations that French had. (p.13)

Though these actions were aimed to strengthen Arabic, however the Algerian society was still influenced by the French language and culture. In 2000, in order to adapt the local market with the global norms, Algeria made major social and economic changes. This new reality led Algerian policy makers to rethink their language planning, putting more emphasis on the English language to help the Algerian society follow the trend of development and modernity. Consequently, at the educational level, the English language was introduced earlier (1st year middle school). Furthermore, many private language schools specialized in English teaching opened providing training for specific needs. These schools offer General English as well as English for Specific Purposes courses. Their brochures offer a variety of course formulas: one-to-one, small groups and combination training formats in addition to specialist seminars, simulations, needs analysis and consultancy.

To conclude, Arabic, Tamazight, French and English are considered as components of today's Algerians' identity. The Algerian government being aware of this reality has tried to find a balance between the national and the foreign languages in the educational system by introducing each language at an appropriate level. At the same time, more importance is given to the English language which is considered as a facilitating tool to engage in the worldwide process.

\subsection{Target situation analysis}


Lawyers are among the different working groups who express an emergent need to learn English. Indeed, in a given society, the various fields of economic exchange need human competencies particularly those who master law to regulate and control the legacy of the different documents. Yet, in many situations these lawyers or administrators need English to fulfill their work. However, only a few of them working with the ministries show proficiency in the English language. Concerning local offices, the working staff is not able to deal with the situations in which English is needed. In 2011, Hamzaoui and Lamri explored the Algerian situation regarding the use of English in the field of law and administration and the frequency of English use in their workplaces, especially the fields that employ graduates from law faculties. The results of the study revealed that English is increasingly used in their field of work and "that Algerian lawyers and officers need English for communicative purposes in their professional settings" (Hamzaoui\& Lamri, 2011, p.35). Moreover, in almost all cases, Algerian candidates cannot expect to be selected for vocational tasks because they lack communicative and language skills in English. Accordingly, professionals insist on the positive impact that will bring English for legal purposes on students' career. Furthermore, the results showed that, Algerian officers cannot interact with English speakers fluently and they have to call for a translator to avoid misinterpretation. The managers also declared that constitutionally, the official language in the Algerian administration is Arabic; for this reason, they transmitted the documents to legal translators to pass up confusion or misreading(Hamzaoui\&Lamri, 2011).

\subsection{Challenges in reading}

Knowing languages is crucial to comprehend sciences. Adegboye (1993) argues that English language proficiency is essential for successful academic achievement. Indeed, one important problem for ELP students is to comprehend what they have to read. In fact, reading is a highly interactive and complex process that "involves knowledge of the language system, the sociocultural context, the type of text, and the objective of the reading" (Tesser, 2005, p.5). Thus, the reader is appealed to make use of the sensory, syntactic, semantic and pragmatic knowledge that interrelates together in complex ways during the reading process to allow comprehension (Davies, 1995, p.64). This is why reading exposure is highly recommended in ELP context, as it helps students to be familiarized with the terminology and the language structures used in their specialty, and to improve their comprehension of different texts. Both printed and digital texts can constitute an appropriate source for legal vocabulary acquisition.

In the past decades, communication in general and learning in particular were based on printed texts. Access to computing technology was limited to some people and used only for specific purposes. However, today's learners labeled the "digital generation" adopt the new technological supports; their main reading and communication activities are done through digital texts by exchanging SMSs or emails. In addition, they acquire information digitally rather than from printed texts. 
Likewise Algerian learners tend to use more and more ICTs. In other words, today computer keyboard and digital screen are parts of students' lives. This computer skill helps to shift from printed to digital text.

Mixing face to face and distance e-learning can provide an instructional balance between language and technology that helps to update students' knowledge and stimulate their learning motivation. The blended learning approach "combines the best elements of online and face-to-face learning. It is likely to emerge as the predominant model of the future" (Watson, 2008, p.3).

\subsection{Blended learning approach}

Blended learning is also referred to as "hybrid learning"; it is "the concept that includes framing teaching learning process that incorporates both face to face teaching and teaching supported by ICT" (Lalima \& Kiran,2017, p.131) it combines the best characteristics of a traditional classroom with an online insertion of specific content to specific learners. In 1998, Marques et al. set up a new teaching model “...that integrates conventional classroom teaching and Web-based distance learning technologies to form a hybrid instruction model for a teaching paradigm that can be easily applied toward learner-centered education" (Marques et al, 1998, p.90).

However, there is no consensus on the definition of Marques et al. Clark (2002) argues that blended learning is not new and maintains that after each innovation, a kind of blending arises starting from printing, media broadcast, personal computers, CD-ROM, and the Internet. In the same vein, Thorne (2003) describes blended learning as "a mix of traditional forms of classroom training and one-to-one coaching with Multimedia technology, CD ROM video streaming, Virtual classrooms, Voicemail, email and conference calls, online text animation and video streaming" (p.16). In education, each introduced technology is blended with the existing situation which implies that blended learning is the mixture of traditional classroom teaching with computer-based materials. However, according to Clark (2002) internet is considered as the main learning source and can manage several of the blended elements in a fashionable way to learners.

This new trend in education is nowadays the subject of debate among researchers who provide different views concerning how blended learning should be implemented. This is why it is relevant to deepen the different notions related to the blended learning approach so as to adopt and adapt it to the case of ELP Algerian students.

In the blending process, the time spent online and the technology utilized are very important (Heinze and Procter, 2004). The following figure summarizes the new conception of blended learning in relation to Online Based Education (OBE). 


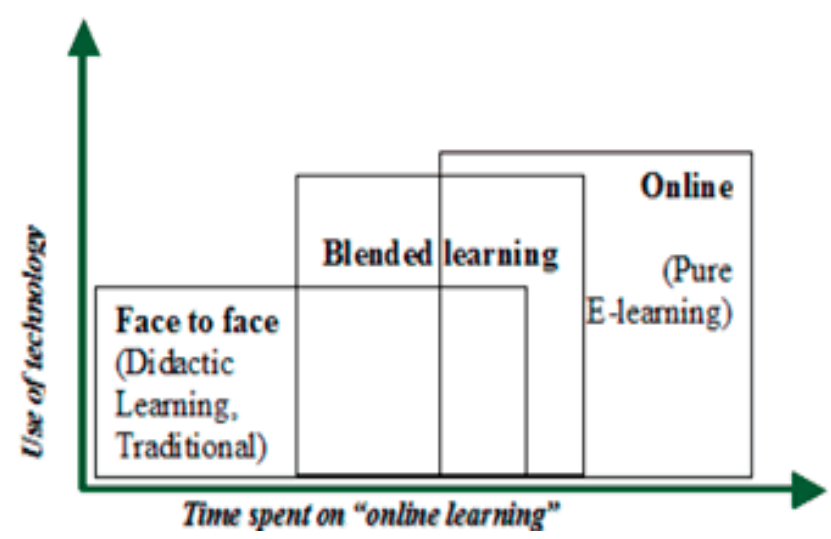

Figure 1. Conception of Blended Learning (Heinze and Procter, 2004, p.1)

As presented in figure 1, blended learning is seen as "learning which combines online and face to face approaches." (Department of Education and Training, 2003 as cited in Heinze and Procter, 2004, p.1). There are overlaps between classroom courses, which use some types of internet tasks, and the online learning, which mixes some sorts of in person activities. Procter (2003) enriches this vision by stating that "Blended learning is the effective combination of different modes of delivery, models of teaching and styles of learning" (p.3). The blended learning approach, that uses internet and classroom in a FL context, is seen as a pedagogical solution to overcome learning/teaching difficulties, with "the integration of new mobile technologies and online media is proving highly effective in helping schools meet the expectations of 21 st century learners while addressing the challenges of limited resources and the special needs of many students" (Victorian DEECD, 2012, p.5).

\section{The study}

As mentioned before, in Algerian Universities (which are all state universities), Law Faculties are aware of the importance of English for future officers and lawyers. However, the time devoted to English teaching to Law students is only one hour and a half per week during five years (three years at the Licence ${ }^{2}$ level and two years in Master's studies). Moreover, the course content does not focus on these students' English language needs as it provides mainly general English activities and/or business terminology. After graduation, Law students have a low or intermediate level of reading comprehension.

Thus, after identification of Law students' English language needs, the main purpose of the present study is to design a blended course that will namely focus on Law students' reading comprehension in an ELP context (a major need), and see whether this course can answer these students' English language needs.

2The Licence degree is the equivalent of the BA degree 


\subsection{Research method}

Denning (2008) states that "If the question is about cause-effect - meaning that a result, or an effect, is caused by what the researcher is doing - the type of research design should be experimental" (p.8). The experimental design best suited this study as it allowed to investigate ELP students' reading problems and compare two different groups of learners under controlled conditions.

\subsection{Participants}

The participants of the study were first year Master's students at Tlemcen University (Algeria) specialized in 'public policy'. Among this group of 37 students a sample population of 19 students was selected for the experiment. The selection of the sampling technique used in any research design is important for the reliability of the results. Then the present study used the probability sampling which gives all the individuals in the population equal chances of being selected. Within this type of sampling the simple random sampling technique was opted for, i.e. the researchers took the list of students and choose at random 19 students out of the 37 first year Master's students. The remaining 18 students acted as a control group. It should be noted that their English teacher accepted willingly to test the feasibility of blended learning with his students. Then, the topics of the lectures were closely related to their field of study.

The students involved in this investigation were Baccalaureate holders who learnt English for at least seven years before entering university. Then, in the Department of Political sciences and International Relations, they learned English for three years at the Licence level to embark in their fourth year in their master's studies. To sum up, the informants under study learned English for at least ten years when the experiment was undertaken.

\subsection{Instrument}

To assess the effectiveness of the blended approach on ELP students' reading comprehension and the appropriacy of the teaching materials and procedure, the test was used as research instrument. This tool is a valuable source of information to evaluate the influence of a variable under specific conditions with specific subjects. In this view, Bachman (1990) suggests that in addition to measuring learners' performances, tests can, also be considered as a kind of research instrument used to analyze the teaching and testing situation "...in a language programme, a number of things are evaluated other than learner proficiency. These may include the effectiveness of particular methods or materials... learner/teacher satisfaction, teaching effectiveness, etc." (Council of Europe, 2001, p.177).

In this study, parametric sample reading comprehension tests were designed and administered as pre, while and post-tests, i.e., at the beginning of the experiment, then after the first unit, and at the end of the academic year. These tests were aimed 
to evaluate students' progress, and to test the hypothesis that the blended learning approach and the use of new technologies can help ELP students to overcome their reading comprehension problems. The proposed instrument was a printed reading text with three-word choices to be selected according to the sentence and word meaning. This method is known as Core Reading Comprehension Maze Test and it is "a task that measures how well students understand text they read silently. After the first sentence, every seventh word in the passage is replaced with the correct word and two other distracters. Students choose the one that fits best the rest of the passage." (Milone,2008, p.150).

\subsection{ELP blended course design}

Teaching ELP is becoming more and more important because of increasing demand to recruit lawyers and officers able to communicate in English in their field. Yet before designing an appropriate ELP course, it is crucial to identify the specific language needs of these students. For this reason, a needs analysis of the target population was undertaken by Hamzaoui and Lamri (2011) and constituted the basis for the design of the present course and the selection and organization of the teaching materials.

The NIA revealed that these students have lexical, phonological and syntactic difficulties. In addition, they lack vocabulary knowledge as they are not able to paraphrase the meaning of some sentences in the text, i.e., they need to perform their linguistic and strategic skill.

The designed course was based on Content and Language Integrated Learning (CLIL) to develop students' content knowledge and English fluency at the same time; it focused on promoting the reading comprehension of ELP students. However, as highlighted before, the teaching time devoted to English did not allow giving the necessary input to these future professionals in the classroom. Therefore, a blended Course Objectives learning approach was opted for, i.e., the content was delivered face to face and online via a Moodle platform.

The main objectives of the ELP blended course were to help the students build a legal terminology corpus and train them to use different reading strategies that would lead to comprehension.

The aim of each unit was: first, to provide students with knowledge of legal topics as British and American legal systems; second, to expose learners to a large quantity of meaningful authentic materials as extracts from texts of law and administrative documents; third, to help students acquire legal English terminology and phrases, through systematic text comprehension and language tasks as comprehension questions, matching exercises and explaining definitions and translation; Finally to train them to use different reading strategies as predicting, scanning and guessing meaning from context. 


\subsubsection{ELP sample lessons layout}

Concerning lesson components, each unit was divided into five parts. Each part took one classroom session and perhaps more (between $1 \mathrm{~h} 30 \mathrm{~m}$ and $2 \mathrm{~h}$ ). A total teaching time average of ten hours was planned in the classroom and a minimum of ten other hours was devoted to tasks outside the classroom, i.e., the teaching time was doubled thanks to the blended approach.

- Part one: pre-reading tasks. The first two tasks were completed in the classroom, while the other ones were done online.

- Part two: classroom tasks (while reading).

- Part three: post-reading comprehension tasks. The first task was completed in the classroom, and two other ones were done online.

- Part four: translation and language tasks

- Face to face teaching

- Part five: transfer. Acquired reading knowledge was transferred to real situation tasks (Online tasks).

\subsubsection{Course design}

A sample course was implemented in the 'e-learn' platform of Tlemcen University website. Students could have access via two links www.univ-tlemcen.dz/ orhttp://elearn.univ-tlemcen.dz/.

\subsubsection{Course presentation on the website}

The user interface is presented in Figure 2 below. The structure of the website has four frames. On the top of the website we have the name of the platform and the user. Then, the left side comprises communication hyperlinks. The right side includes user name and pass word three buttons. The fourth frame is, at the central part of the screen, content frame presenting the courses titles.

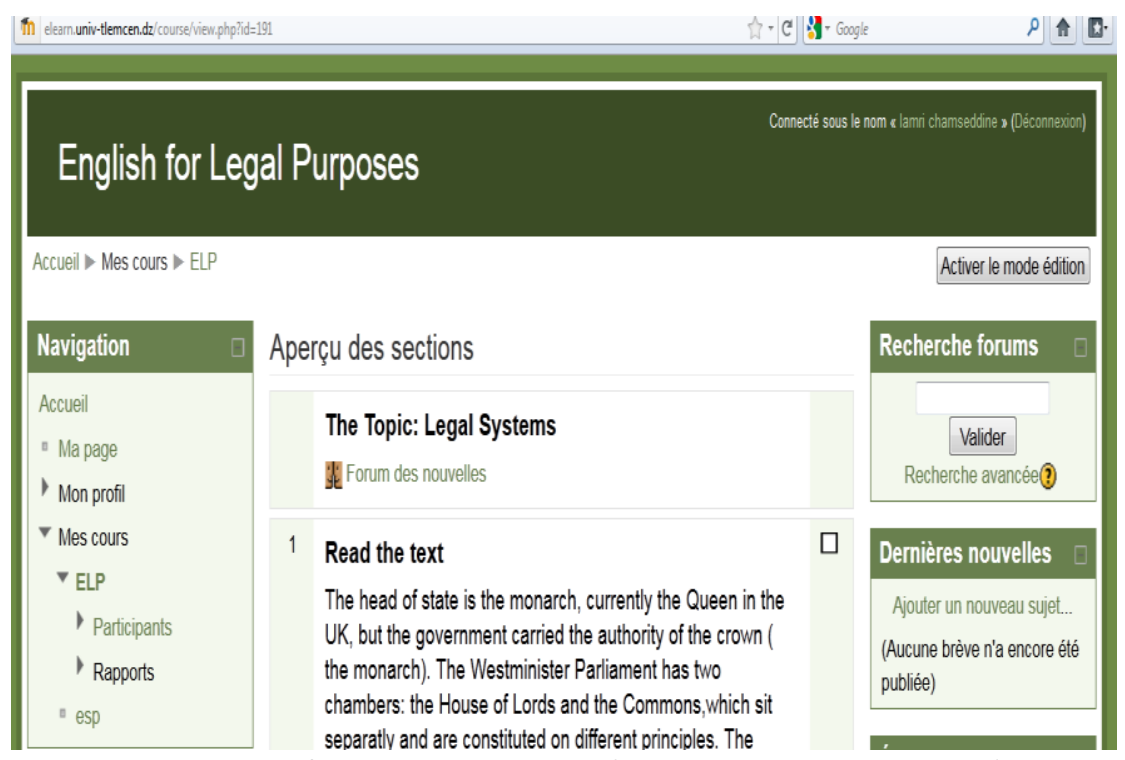

Figure 2. View of ELP course in Tlemcen University web site interface 
The authorized students inserted their user names and passwords, then connected and worked on the platform. Regarding the structure and the pattern of the site, the version of Moodle programme (1.4 - 31/8/2004) offered by the university platform was not a recent one, and therefore limited in terms of technical help. Nevertheless, elearn univ-tlemcen.dz provided a full range of information related to the pedagogical, scientific and social activities in Tlemcen University that would be of interest for students. To provide a detailed description of the website each of its components will be presented below.

\subsubsection{Course description page}

It described the course objectives, outline, time load, place for classroom activities, and the instructor information.

\subsubsection{Lecture page}

This page allowed students to see directly the lectures (texts and tasks) programmed for each week on the platform, and to download them into their personal computers.

\subsubsection{News page}

In this page, only the university webmaster could add news, delete or modify existing ones. In addition, the teacher could present the latest news on the Home page which every user could consult.

\subsubsection{Communication}

In addition to e-mails, the web site offered communication opportunity through chats and forums.

\subsection{Topic and text selection}

According to students' requirements and teachers' suggestions, various topics were proposed to set up an ELP syllabus. For the present course, the researcher selected the most commonly and widely studied topics in the curriculum of law and political sciences. These were related to the Anglo-Saxon legal systems and international laws. As these topics were closely associated to students' field of study, it was believed that they would motivate students to learn English. Indeed, it is commonly known that the content serves the language if a relevant academic topic area can provide meaningful context in which students can reach language objectives.

After choosing the topics, the researcher selected some texts to be inserted in the course. Yet, it was important to measure the ease with which a text could be read and understood, i.e., text readability.

Various formulas exist and the most used ones are the Flesh and Dale-Chall formulas. These formulas are equations that study text features and its difficulty. In this study, text readability estimation was tested according to Dale-Chall and Flesch Index formulas in order to see if the students can read and study the texts. The 
majority of texts were scored 11-12 in Dale-Chall formula and 54.2/100 in Flesch Index, i.e., they were fairly difficult and estimated 'IV Adept' according to NAEP ${ }^{3}$ proficiency levels and the reading-grade-level equivalents. In other words, these texts have specific content and can be used for upper intermediate level students.

\section{Results}

As formulated in the research hypothesis, this study aimed at investigating, first, whether a blended approach to ESP teaching would raise students' motivation to learn English; and second whether the designed ELP course would improve students' reading competence. For the first purpose, users' login frequency was used to see to what extent students were motivated to use the Moodle platform to learn; and for the second one, the time spent on text reading and the scores obtained for the tests were considered to evaluate students' reading competence improvement.

\subsection{Users' login frequency}

The students' actions in the website were recorded by the web server. These data include student's identity, Internet Protocol (IP) numbers, the date of the action, and the action itself. However, we were not able to collect the total amount of time spent by each student online because, as already mentioned these data require Moodle 1.9 or following versions and the e-learn platform of Tlemcen University was designed with Moodle 1.4 which did not allow for that.

Nevertheless, the platform provided us with the total number of connections done by the students during the whole period of the experiment. From January 6, 2014 to May 25, 2014, a total of 345 visits were recorded by the web server. Five students logged in only once; these students may have found technological difficulties or simply were not motivated by the experiment. Four other students logged in eleven to fourteen times, fewer than the number of lectures provided (fifteen); nevertheless, they did their homework and therefore increased their reading time. Ten students, i.e., more than $50 \%$ of them, logged in more than fifteen times, i.e., more than once every lecture. According to these results, it can be concluded that the majority of students were motivated to learn online and consequently increased their learning and reading time.

\subsection{Test scores}

The present experiment sought to verify the efficiency and impact of the proposed ELP course on the whole class and not on individual reading achievement. For this, the mean scores obtained by both groups of students were compared, i.e., the experimental group and the control group.

\footnotetext{
3. The National Assessment of Educational Progress (NAEP) is a program initiated by the U.S. Department of Education to study students' academic achievements.
} 
It should be noted that four participants in each group (experimental and control group) sat for the pre- test, but they did not do the while- and post-tests. They were probably not motivated to continue the experiment knowing that they were free to participate. Therefore, only students who participated from the beginning of the experiment to the end were taken into consideration, i.e., fifteen in the experimental group and fourteen in the control one.

The analysis of students' reading achievement test revealed interesting results summarized below.

\subsubsection{Pre-test analysis:}

In January 2014, the pre-test was administered in a form of a reading Maze test (see Appendix A) composed of twenty three response items. Each item consisted of the original word and two other words that would not make sense if substituted in the passage in place of the original correct word. The text selected for the pre- and whiletests was estimated between 7-8 in Dale-Chall formula, and 64.8/100 in Flesch index, i.e., the text is appropriate for standard readers. With regard to the results, the students of both groups obtained an average of nearly $55 \%$ of correct answers; and it was done in approximately 13 minutes. It is clear that we were dealing with homogeneous groups in terms of their reading ability.

\subsubsection{While-test analysis:}

The while-test, took place in March 2014. After receiving classroom and online instruction for more than two months, the same text was administered again. The control group obtained $61.50 \%$ of correct answers and the experimental group had $74.20 \%$ of correct answers. In addition, 9 minutes 42 seconds were recorded, as an average time of test performance for the first group and 9 minutes 06 seconds were recorded for experimental group. In the pre- test, the difference between the two groups in terms of time performance was 44 seconds; this difference decreased to 36 seconds in the while test. It seems that the designed ELP lessons helped students to improve their reading speed. In addition, what is noticeable is that the students of the experimental group made fewer mistakes than the control group, which reveals a higher comprehension level.

\subsubsection{Post-test analysis:}

At the end of the academic year (May 2014), a post-test was implemented (see Appendix B) to confirm the preliminary results obtained from the pre- and whiletests. A more difficult and specialized text was proposed, according to Dale-Chall formula the text was estimated between 13-15, and 15.5/100 according to Flesch Index, i.e., the text was appropriate for adept readers. The students obtained $58.7 \%$ of correct answers in the control group, and $76.97 \%$ of accurate responses in the experimental group. 


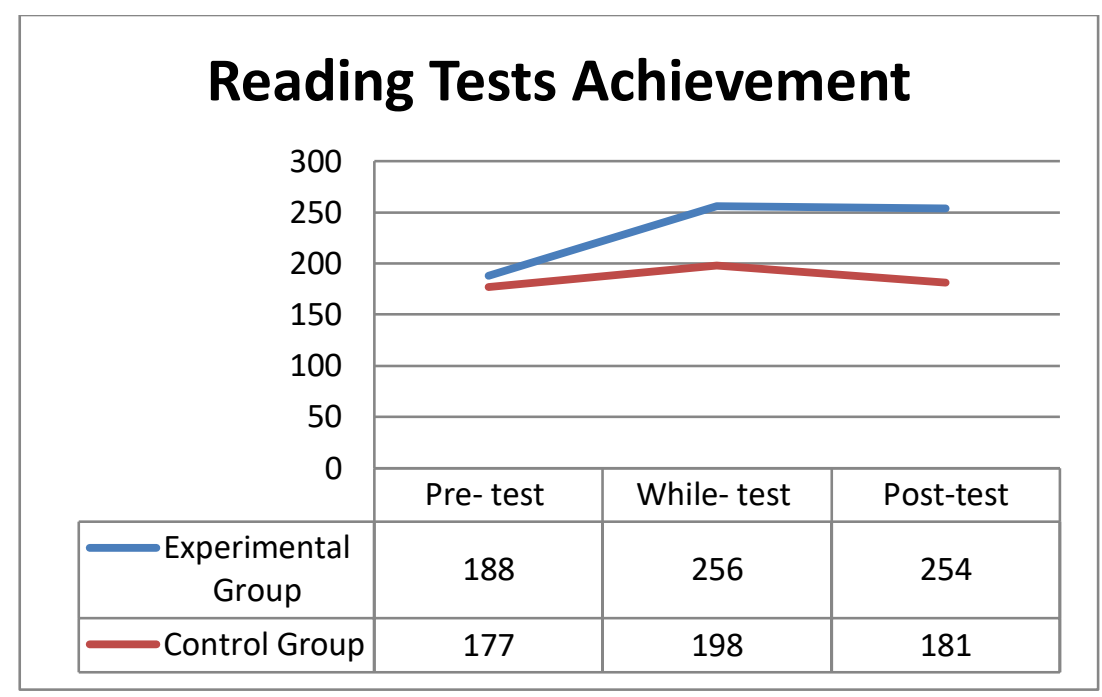

Figure3. Reading Tests Achievement

Regarding time accomplishment, 9 minutes 5 seconds were recorded for the first group and 7 minutes 4 seconds for the second.

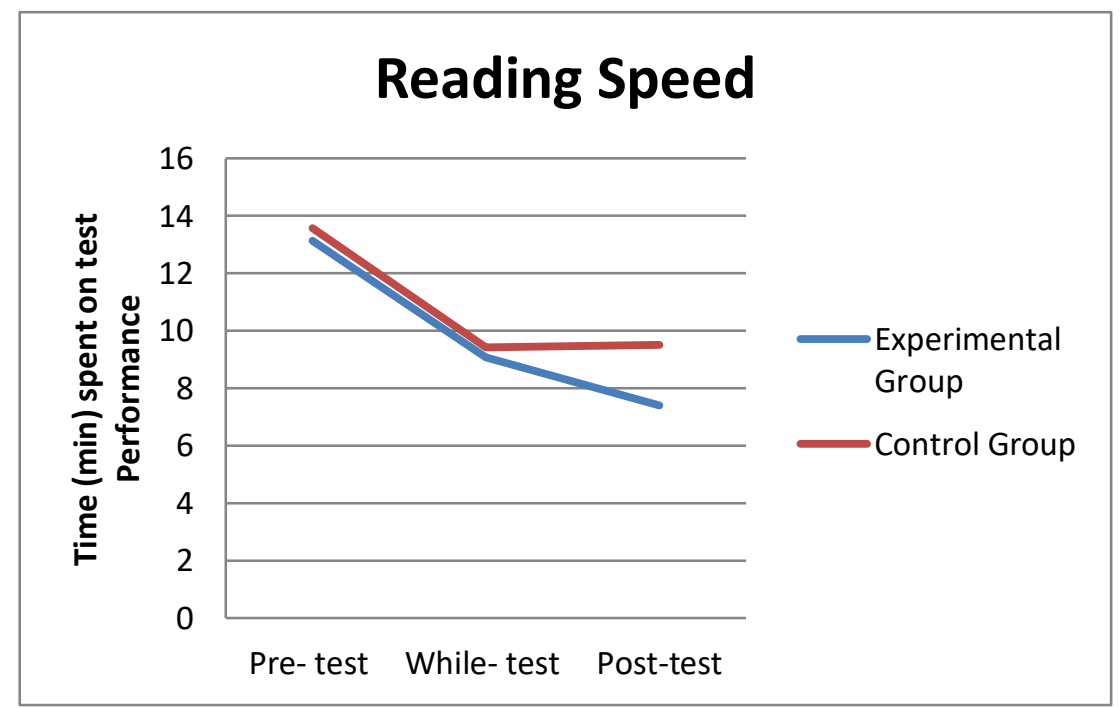

Figure 4. Reading Speed

Significant statistical differences were recorded between the two groups. Though ordinary classroom students improved their reading abilities as proved by the tests, the experimental students who engaged in blended learning made more significant progress in reading as they made fewer mistakes and they decreased considerably their reading time. 


\section{Discussion}

The analysis of the data collected in this study revealed interesting results regarding the feasibility and the outcomes of the use of a CLIL syllabus implemented through a blended approach in an ELP/ESP context.

The users' login frequency showed that the majority of the experimental students (more than 75\%) used the Moodle platform after every lecture, this action may reveal their motivation to learn via technology, thus, allowing them to increase their learning and reading time; and "it is, by now, inevitable that methods of teaching and learning should include E-learning components that are based on the computer environment" (Kotzer \& Elran, 2012).

Hans and Hans (2013, p.16) argue that "students' purpose for reading is often to obtain information about a subject they are studying, thus reading for content information in the language classroom gives students an authentic purpose for reading". As aforementioned, intensive exposure to ELP texts can help students to be familiarized with the language structures used in their specialty, and to improve their comprehension. In fact, the proposed tasks on the platform assisted the students to use some reading strategies which helped them read and comprehend texts quickly. In addition, these tasks supplemented the classroom input and helped students to memorize the specific jargon and language structures used in their context. Furthermore, if students have access to Web sites and authentic reading materials, they are exposed to culture in all its variety. Reading can give students knowledge about lifestyles of the target language people. Consequently, teaching reading is important to promote the linguistic, sociolinguistic and cultural competencies (Hans \&Hans, 2013).

As a result, the tests scores revealed that students of the experimental group, who were homogenous in terms of their reading ability with the control group at the beginning of the experiment, could achieve in a short period of time, i.e. a semester, a satisfactory reading competence. They showed good knowledge of legal jargon and satisfying comprehension of legal texts written in English as compared to the control group. In addition, they reduced the time spent on reading a text. All these results seem to support the present research hypothesis which stipulates that adopting a course based on Content and Language Integrated Learning (CLIL) combined with a blended approach to teach ELP will better motivate learners and help them to improve their reading competence in a short span of time.

\section{Conclusion}

This study proposed the integration of technology to compensate for lack of teaching time in an ESP context and to improve students' language skills competencies namely the reading competence. The results reveal that the Moodle platform is an efficient means for teachers to design new course materials. Moreover, online tasks motivate ELP students to learn English. To overcome the problem of lack of time, instructors 
can supplyhis students with additional different learning resources. Moodle also makes it possible for students to have online discussions allowing them to help each other. The former create an opportunity to communicate immediately with other course mates or with an instructor, while chats create a space for discussion and opinion expression. On the other hand, these tools allow teachers to discover the difficulties faced by students during the lectures or the completion of a task. In addition, the blended approach increases the teaching and learning time and provides a wide selection of texts and tasks for students who can perform them whenever they feel it necessary. These facilities will help ELP students to improve not only their reading comprehension, but also their competence in the other skills. To conclude a blended learning approach combined with CLIL is beneficial for ELP students to develop their content knowledge and improve their reading competence.

\section{References}

Adegboye, A. O. (1993). Proficiency in English language as a factor contributing to competency in Mathematics. Education Today, 6(2), 9-13.

Benrabah, M. (2007). Language in Education Planning in Algeria:Historical Development and Current Issues. In Language Policy. (2007)6; 225-252. Springer.

Council of Europe. (2001). Common European framework of reference for languages: Learning, teaching, assessment. Cambridge, U.K: Press Syndicate of the University of Cambridge.

Clark, R. C. (2002). The New ISD: Applying Cognitive Strategies to Instructional Design. ISPI Performance Improvement Journal, 41(7), 10-16. doi:10.1002/pfi.4140410704

Coleman, H. (2010). The English Language in Development. A paper commissioned by the British Council. Retrieved on Dec 9, 2014 from https://www.teachingenglish.org. uk/sites/teacheng/files/UK011-English-Language-Development.pdf

Dale, E., \&Chall, J. (1995). Readability Revisited: The New Dale-Chall Readability Formula. Cambridge, Massachusetts: Brookline Books Inc.

Davies, F. (1995) Introducing Reading. London: Penguin Books.

Denning, J. (2008).Guide to Education Research for Journalists. The Hechinger Institute on Education and the Media at Teachers College, Columbia University. Retrieved from, http://www.articlesbase.com/education-articles/experimental-method-1512721.html

Department of Education and Training. (2003). Blended Learning, NSW Department of Education and Training.

Gordon, D. C. (1966). The Passing of French Algeria.London: Oxford UniversityPress.

Hamzaoui, H., \&Lamri, C. (2011). An English course for Algerian Law and Administrative Science students.ESP Across Cultures, 8, 23-43.

Hans,A.,\& Hans,.E.(2013).Role of Computers in Reading Skills. IOSR Journal Of Humanities And Social Science (IOSR-JHSS) Volume 15, Issue 4 (Sep. - Oct. 2013), PP 15-19 e-ISSN: 2279-0837, p-ISSN: 2279-0845. www.Iosrjournals.Org

Heinze, A., \& Procter, C. (2004) Reflections on the Use of Blended Learning, Education in a Changing Environment Conference Proceedings, 13 ${ }^{\text {th }}$-14 th September 2004.f

Kotzer, S., \& Elran, Y. (2012). Learning and teaching with Moodle-based e-learning environments, combining learning skills and content in the fields of Math and Science \& Technology. In Proceeding of 1st Moodle Research Conference (pp. 122-131). Crete-Greece: Heraklion.P122 
Lalima, *., \& Kiran, L. D.(2017). Blended Learning: An Innovative Approach. Universal Journal of Educational Research 5(1): 129-136, 2017. DOI: 10.13189/ujer.2017.050116

Marsh, D. (2012). Blended learning: Creating learning opportunities for language learners. New York: Cambridge University Press.

Marques, O., Woodbury, J., Hsu, S.,\& Charitos, S. (1998). Design and Development of a Hybrid Instruction Model for a New Teaching Paradigm. Proceedings of 28th Annual Frontiers in Education Conference. Moving from 'Teacher-Centered' to 'Learner-Centered' Education, 1, 90-94. doi: 10.1109/FIE.1998.736810 .

Miliani, M.(2003).Foreign Language Teaching Approaches, Methods and Techniques. Oran: Dar El Gharb.

Milone, M. (2008). Assessing Reading: Multiple Measures for Kindergarten Through Twelfth Grade. Consortium On Reading Excellence. Califorina. Arena Press.

Procter, C. (2003). Blended Learning in Practice. In Inaugural Education in a Changing Environment conference. Salford, University of Salford,.

Tabory, E., \& Tabory, M. (1987). Berber unrest in Algeria: lessons for language policy. International Journal of the Sociology of Language, Volume 1987, Issue 63, Pages 63-80, ISSN (Online) 1613-3668, ISSN (Print) 0165-2516, DOI: https://doi.org/10.1515/ijsl.1987.63.63.( 26 January 2016)

Tesser, C.C. (2005). The Role of Building Reading Comprehension. Retrieved on Nov 3, 2012from, http://apcentral.collegeboard.com /apc/public/repository/Spanish_Lang_.pdf

Thorne, K. (2003). Blended learning: how to integrate online and traditional learning. London: Kogan Page Limited.

Victorian Department of Education and Early Childhood Development (DEECD). (2012). Blended learning A synthesis of research findings in Victorian education 2006-2011. Retrieved from, https://www.education.vic.gov.au/documents/about/research/blended learning.pdf

Watson, J. (2008). Blended learning: The convergence of online and face-to-face education. Vienna, VA: North American Council for Online Learning.

\section{Appendix A. Pre-While tests}

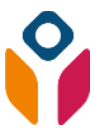

Curriculum-Based Measurement: Maze Passage: Examiner Copy

Student/Classroom: Examiner: Assessment Date:

Passing an Act

Professional English in Use Law

All Acts must be submitted to both Houses of parliament in the draft from of a Bill. The legislative process involves three readings (in) both houses. At the first reading, (the) title is read to members of (Parliament) (MPs); at the second reading, MPs (debate) proposals. Then a standing committee will (scrutinize) the provisions in the Bill and (may) amend it to 
ensure that it (enshrines) the principles debated and approved at (the) second reading. This is reported back (to) MPs. At the third reading, the (bill) is re-presented. The Bill then goes (through) readings in the upper house. The (actual) drafting of the legislation is undertaken (by) Parliamentary Counsel. Finally, a bill must (receive) Royal Assent from the monarch before (it) becomes law on a specified date. (In) fact, this stage has been reduced (to) a formal reading of the short (title) of an act in both Houses (of) parliament and is now a formality. (Government) Bills are introduced by the Government; (Private) Members Bills are proposed by MPs. (Both) methods may result in Public Acts (that) govern the general individuals or institutions.

Readability Estimation

Formula Value

Dale-Chall 7-8

Flesch Index 64.8/100 (plain English)

Curriculum-Based Measurement: Maze Passage: Student Copy \#/Correct: \#/Errors:

Student Name: Classroom: Date:

Passing an Act

Professional English in Use Law

All Acts must be submitted to both Houses of parliament in the draft from of a Bill. The legislative process involves three readings (release, in, basin) both houses. At the first reading, (the, face, over) title is read to members of (Parliament, goat, broken) (MPs); at the second reading, MPs (went, upset, debate) proposals. Then a standing committee will (scrutinize, prevent, food) the provisions in the Bill and (fought, may, amused) amend it to ensure that it (son, solemnly, enshrines) the principles debated and approved at (vanish, rain, the) second reading. This is reported back (square, save, to) MPs. At the third reading, the (bill, side, throughout) is re-presented. The Bill then goes (dirty, husky, through) readings in the upper house. The (madly, actual, mend) drafting of the legislation is undertaken (rest, by, flown) Parliamentary Counsel. Finally, a bill must (neatly, took, receive) Royal Assent from the monarch before (it, promptly, sky) becomes law on a specified date. (Wood, Prevent, In) fact, this stage has been reduced (to, opinion, began) a formal reading of the short (title, morning, straight) of an act in both Houses (of, reject, soft) parliament and is now a formality. (Basket, Government, Glamorous) Bills are introduced by the Government; (family, Private, clearly) Members Bills are proposed by MPs. (Both, Amuse, Credit) methods may result in Public Acts (that, cord, went) govern the general individuals or institutions. 
www.interventioncentral.org • Copyright () 2009 Jim Wright

\section{Appendix B. Post Test}

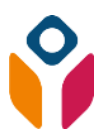

Curriculum-Based Measurement: Maze Passage: Examiner Copy

Student/Classroom: Examiner: Assessment Date:

Sources of international law

From Wikipedia, the free encyclopedia

A source of international law is where an international decision maker or researcher looks to verify the substantive legal rule governing a legal dispute or academic discourse. The sources of international law applied (by) the community of nations to find (the) content of international law are listed (under) Article 38.1 of the Statute of the (International) Court of Justice: Treaties, international customs, (and) general principles are stated as the (three) primary sources; and judicial decisions and (scholarly) writings are expressly designated as the (subsidiary) sources of international law. Many scholars (agree) that the fact that the sources (are) arranged sequentially in the Article 38 of (the) ICJ Statute suggests an implicit hierarchy (of) sources.[5] However, there is no concrete (evidence), in the decisions of the international (courts) and tribunals, to support such strict (hierarchy), at least when it is about (choosing) international customs and treaties. In addition, (unlike) the Article 21 of the Rome Statute (of) the International Criminal Court, which clearly (defines) hierarchy of applicable law (or sources (of) international law), the language of the (Article) 38 do not explicitly support hierarchy of (sources).

Readability Estimation

Formula Value

Dale-Chall 13-15

Flesch Index 15.5/100

www.interventioncentral.org • Copyright $@ 2009$ Jim Wright

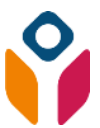


Curriculum-Based Measurement: Maze Passage: Student Copy \#/Correct: \#/Errors:

Student Name: Classroom: Date:

Sources of international law

From Wikipedia, the free encyclopedia

A source of international law is where an international decision maker or researcher looks to verify the substantive legal rule governing a legal dispute or academic discourse. The sources of international law applied (by, average, rinse) the community of nations to find (drawer, the, ear) content of international law are listed (expand, top, under) Article 38.1 of the Statute of the (International, besides, rang) Court of Justice: Treaties, international customs, (ate, button, and) general principles are stated as the (healthy, three, property) primary sources; and judicial decisions and (rightfully, scholarly, money) writings are expressly designated as the (subsidiary, pleasant, rubbery) sources of international law. Many scholars (ours, agree, page) that the fact that the sources (politely, beyond, are) arranged sequentially in the Article 38 of (the, communicate, skin) ICJ Statute suggests an implicit hierarchy (of, defeated, bring) sources.[5] However, there is no concrete (awoke, onto, evidence), in the decisions of the international (breezy, courts, she) and tribunals, to support such strict (charming, hierarchy, water), at least when it is about (reach, choosing, doubt) international customs and treaties. In addition, (unlike, written, cooperative) the Article 21 of the Rome Statute (of, rarely, uptight) the International Criminal Court, which clearly (defines, shake, curve) hierarchy of applicable law (or sources (of, innocent, education) international law), the language of the (Article, property, nut) 38 do not explicitly support hierarchy of (melt, sources, icy).

www.interventioncentral.org • Copyright $@ 2009$ Jim Wright

\section{Copyrights}

Copyright for this articleis retained by the author(s), with first publication rights granted to the Journal.

This is an open-access article distributed under the terms and conditions of the Creative Commons Attribution license (CC BY-NC-ND) (http://creativecommons.org/licenses/by-nc-nd/4.0/). 